\title{
Peptides Related to the Carboxyl Terminus of Human Platelet Factor IV with Antibacterial Activity
}

\author{
Richard P. Darveau, James Blake, * Carrie L. Seachord, Wesley L. Cosand, * Mark D. Cunningham, \\ Linda Cassiano-Clough, and Grace Maloney \\ Immune Science and *Peptide Chemistry Groups, Bristol-Myers Squibb Pharmaceutical Research Institute, Seattle, Washington 98121
}

\begin{abstract}
A peptide ( $\mathrm{C13}$ ) corresponding to the last 13 amino acids of the carboxyl terminus of human platelet factor IV was found to be antibacterial. Amino acid substitutions predicted to disrupt either the amphipathic or $\alpha$-helical nature of $\mathrm{C} 13$ rendered the peptide inactive. Antibacterial activity was demonstrated in normal human serum on bacteria which had been previously exposed to low levels of cefepime, a $\boldsymbol{\beta}$-lactam antibiotic. Peptide analogues were examined for more potent antibacterial activity in an antibacterial assay that employed normal human serum and low levels of cefepime. A peptide analogue (C18G) with 80-fold more antibacterial activity than $\mathrm{C13}$ was identified. Studies in C8-deficient sera confirmed an essential role of human serum complement for optimal antibacterial activity. Additional studies showed low levels of cefepime, although not essential, enhanced the antibacterial activity of C18G. Animal protection experiments demonstrated that either peptide C18G or an analogue with all $D$ amino acids (C18X) significantly increased the survival of neutropenic mice when coadministered with a low level of cefepime. This work has resulted in the identification of a new group of antibacterial peptides. (J. Clin. Invest. 1992. 90:447-455.) Key words: antibiotics • complement $\cdot$ peptides
\end{abstract}

\section{Introduction}

Bacterial infections in the neutropenic patient remain a major cause of morbidity and mortality despite rigorous antibiotic treatment (1). Efforts to improve the clinical response to antibiotic treatment in these patients include therapies intended to augment the host immune system (2-4) as well as the search for more efficacious antibacterial agents. In the past, new antibacterial agents have either been more bactericidal (5) and less likely to elicit bacterial resistance, or demonstrated more favorable pharmacokinetic properties (6). However, to our knowledge, no new antibacterial agents have been specifically designed to augment the host immune system in the eradication of bacterial infections. It is becoming increasingly clear that the host immune system plays an important role in the eradication of bacterial infections during antibiotic therapy (5). Retrospective clinical analyses have clearly shown that antibiotics are more successful when an intact host defense system is present

Address reprint requests to Dr. Darveau, Immune Science Group, Bristol-Myers Squibb Pharmaceutical Research Institute, 3005 First Avenue, Seattle, WA 98121.

Received for publication 10 December 1991 and in revised form 28 February 1992.

J. Clin. Invest.

(c) The American Society for Clinical Investigation, Inc. 0021-9738/92/08/0447/09 \$2.00

Volume 90, August 1992, 447-455
(1). In addition, both in vitro $(7,8)$ and in vivo studies (9) have confirmed that antibiotic-altered bacteria are significantly more susceptible to polymorphonuclear cell-mediated phagocytosis, a major component of the host immune system involved with bacterial removal. It has been proposed that antibiotic injured bacteria may be adequately handled by immunosufficient hosts but not by immunocompromised patients (5). This may account for some of the antibiotic treatment failures in these patients. We are attempting to improve the clinical response to antibiotic treatment for neutropenic patients by investigating therapies that would kill antibiotic-injured bacteria.

Recently, it has been shown that low concentrations of $\beta$ lactam antibiotics may render bacteria more susceptible to serum-mediated killing $(10,11)$. This is a potentially useful effect for the immunocompromised patient in that serum-mediated killing is the major host defense system for these patients. We have shown that the terminal complement complex was necessary for enhanced antibiotic killing and the $\beta$-lactamaltered bacterial cell surface allowed more terminal complement complex deposition (12). The data suggested that $\beta$-lactam-altered bacteria might be more susceptible to other agents, which in a mechanism similar to complement, need to gain access to the bacterial inner membrane for bactericidal activity. To test this hypothesis, the susceptibility of $\beta$-lactam-altered Escherichia coli to a recently described (13) antimicrobial peptide designated magainin 2 was examined (14). It was demonstrated that $\beta$-lactam-altered bacteria were significantly more susceptible to magainin 2 both in vitro and in vivo mouse protection experiments. The data suggested that therapies designed to kill antibiotic-injured bacteria might improve the clinical response to antibiotic treatment for the neutropenic patient. We proposed that peptide killing of antibiotic-injured bacteria could theoretically mimic the host role in antibiotic therapy of immune-deficient patients.

The possibility that antibacterial peptides could improve standard antibiotic therapy for the neutropenic patient prompted us to examine other potentially useful peptides. Examination of the literature revealed that a common theme for several different antimicrobial peptides was a tendency to form an amphipathic $\alpha$-helical conformation in a hydrophobic environment (15). This conformation may promote interaction of the peptide with the bacterial membrane (16). Independently, a variety of human proteins have been shown to contain amphipathic $\alpha$-helix sequences, which in a similar fashion are believed to facilitate the protein's interaction with membranes $(17,18)$. A peptide was synthesized which corresponded to the last 13 amino acids found at the carboxyl terminus of platelet factor IV (PF4). ${ }^{1}$ In this report we demonstrate that this pep-

1. Abbreviations used in this paper: GVB, gelatin-veronal buffer; NHS, normal human serum; similarly, H-NHS, heat-inactivated NHS; PF4, (human) platelet factor IV. 
tide has antibacterial activity against cefepime-altered bacteria when examined in normal human serum. The unique requirement for both antibiotic and serum for antibacterial activity of the carboxyl terminus of PF4 was used as a basis to examine peptide analogues for antibacterial activity. This process of screening for antibacterial agents deviates significantly from the classic approach of looking for activity in a broth or mediabased system. Therefore, we additionally report the in vitro and in vivo evaluation of a more potent synthetic peptide obtained by this methodology.

\section{Methods}

Reagents and buffers. The following buffers were used: gelatin-veronal buffer with the addition of $0.1 \%$ dextrose $\left(\mathrm{GVB}^{++} ;[19]\right)$ and phosphate-buffered saline (PBS). Cefepime (7-[(Z)-2-(2-aminothiazol-4yl)-2-methoxyaminoacetamido]-3-(1-methylpyrrolidinio) methyl-3cephem-4-carboxylate) and other antibiotics were obtained from Dr. Robert Kessler, Bristol-Myers Squibb Company, Wallingford, CT, as standard laboratory powders. Peptide $\mathrm{C} 13$ and other analogues were synthesized by solid-phase synthesis (20) on a model 430A peptide synthesizer (Applied Biosystems, Inc., Foster City, CA) using Boc/ benzyl-based protection. The assembled peptide resin was treated by hydrogen fluoride/anisole procedure (21), and the cleaved deprotected peptide was purified by high-performance liquid chromatography (HPLC) on a Dynamax C-8 column ( Rainin Instrument Co., Woburn, MA). Highly purified peptides were characterized by analytical HPLC and amino acid analysis. Mueller-Hinton base was obtained from BBL Microbiological Systems, Cockeysville, MD.

Bacterial strains and culture conditions. Escherichia coli strain ATCC 25922 was used for most of the experiments and was obtained from the American Type Culture Collection (ATCC), Rockville, MD. Other $E$. coli strains employed included a $\mathrm{K} 1$ capsule isolate $\mathrm{H} 16$ obtained from Walter Reed Army Institute of Research, Washington, DC, and E. coli AP, which was obtained by passing ATCC 25922 through mice. This process resulted in a strain that was more virulent in the neutropenic mouse model. Klebsiella pneumoniae ATCC 13883 was obtained from ATCC. Pseudomonas aeruginosa M009 was obtained from Dr. Joan Fung-Tomc, Bristol Myers Squibb Pharmaceutical Research Institute. Strains were examined for purity, properly identified, and then stored at $-70^{\circ} \mathrm{C}$. Each week new cultures were made from the frozen bacterial stocks to avoid repetitive subculturing. All strains were grown in adjusted Mueller-Hinton broth containing 50 $\mathrm{mg} /$ liter $\mathrm{CaCl}_{2}$ and $25 \mathrm{mg} / \mathrm{l} \mathrm{MgCl}_{2}$ (19).

Serum. Blood was collected aseptically from five healthy volunteers and allowed to clot at room temperature for $1 \mathrm{~h}$. After $20 \mathrm{~min}$ of incubation at $4^{\circ} \mathrm{C}$ the blood was centrifuged for $15 \mathrm{~min}$ at $1,500 \mathrm{~g}$. Serum was removed, pooled, and then stored at $-70^{\circ} \mathrm{C}$ in small amounts. Shortly before use the pooled normal human serum (NHS) was thawed and kept on ice until mixed with bacteria for the serum bactericidal assay. Where indicated, serum complement was inactivated by heating at $56^{\circ} \mathrm{C}$ for $30 \mathrm{~min}$ (H-NHS). Several different pooled serum sources were used in the course of these investigations and essentially the same results were obtained with each pool. Some experiments employed C8depleted sera and purified C8, both of which were obtained from Cytotech, San Diego, CA.

Determination of the minimum inhibitory concentration (MIC). MICs were determined by the microdilution plate dilution method using adjusted Mueller-Hinton broth (19) with a final inoculum density of $7.5 \times 10^{5} \mathrm{CFU} / \mathrm{ml}$ obtained from mid-exponential phase cells. Plates were incubated for $18 \mathrm{~h}$ at $37^{\circ} \mathrm{C}$. At least three different determinations were performed with each antibiotic for each strain.

Serum bactericidal assay. Bacteria inoculated from overnight cultures were grown to mid exponential phase with or without antibiotic $\left(\mathrm{OD}_{660}\right.$ between 0.35 and $0.5 ; \sim 2-3 \times 10^{8}$ cells $/ \mathrm{ml}$ for cells grown with cefepime and $9 \times 10^{8}$ cells $/ \mathrm{ml}$ cells grown without cefepime).
Cells were diluted without washing to $5 \times 10^{4}$ cells $/ \mathrm{ml}$ in $\mathrm{GVB}^{++}$and $0.05 \mathrm{ml}$ was added to serum in a $1.5-\mathrm{ml}$ Eppendorf vial. For those cells pregrown in antibiotic, the same amount of antibiotic that was present during growth was added for both the preparation and examination of antibacterial activity. Appropriate dilutions of NHS or H-NHS were prepared beforehand in $\mathrm{GVB}^{++}$to a volume of $0.2 \mathrm{ml}$. Cefepime, when present, was added to the serum mixture before the addition of bacteria. The total reaction mixture was $0.25 \mathrm{ml}$. The number of bacteria added to serum was determined by adding $0.05 \mathrm{ml}$ of the bacterial suspension to a tube containing only $\mathrm{GVB}^{++}$and plating at the beginning of the assay. The reaction mixtures were then rotated at $37^{\circ} \mathrm{C}$ for 3 h. Samples were removed at intervals and diluted appropriately for plate count analysis (in triplicate) by the pour plate method (22) using trypticase soy agar. The number of colony forming units was determined after overnight incubation.

The potential for error due to drug carryover effects was eliminated by inclusion of appropriate controls. Inclusion of peptide and cefepime in H-NHS- and C8-deficient sera eliminated the need for drug removal procedures because significant antibacterial activity was detected only in NHS- and C8-replenished sera.

Red blood cell hemolysis assay. The hemolytic activity of the antimicrobial peptides was examined as described by Geoffroy et al. (23) except that red blood cells were added to various concentrations of peptides in $\mathrm{GVB}^{++}$buffer without the addition of bovine serum albumin. In addition, samples were centrifuged for $5 \mathrm{~min}$ at $1,000 \mathrm{~g}$ to remove cell debris before the optical density at $541 \mathrm{~nm}$ was recorded. A $1 / 10$ dilution of cells into distilled water resulted in $100 \%$ hemolysis; this sample was then diluted to generate a standard curve. Optical densities generated after incubation with the various peptides were compared to the standard curve to determine the percent lysis.

Mouse protection experiments. All studies were performed with male CrL:CF1 mice obtained from Harlan Sprague Dawley, Indianapolis, IN. Neutropenia was induced in two separate groups of mice weighing either $19-21$ or $22-24 \mathrm{~g}$ by subcutaneous injection of 250 $\mathrm{mg} / \mathrm{kg}$ cyclophosphamide (Mead Johnson Laboratories, Evansville, IN.). Examination of blood revealed that the level of circulating leukocytes declined to $10 \%$ of normal by the 5 th day after injection and remained depressed for the following 2 days. Mice were challenged intraperitoneally with a log-phase bacterial suspension in PBS $(0.2 \mathrm{ml})$ on the 4th day after cyclophosphamide administration. Probit analysis (24) was used to determine the $\mathrm{LD}_{90}$ for $E$. coli $\mathrm{H} 16$ and $E$. coli AP. For therapeutic protection experiments mice were administered one $\mathrm{LD}_{90}$ which was $2 \times 10^{4} \mathrm{cfu}$ for $E$. coli $\mathrm{H} 16$, and $5 \times 10^{4} \mathrm{cfu}$ for $E$. coli AP.

Mice were divided into four different treatment groups and given injections of either: ( $a$ ) PBS; (b) peptide (either C13, C18G, or C18X); (c) cefepime; or $(d)$ a combination of cefepime and peptide that was mixed before injection. All injections were made in PBS $(0.2 \mathrm{ml})$ and were administered intramuscularly with each injection in separate legs at 1 and $3.5 \mathrm{~h}$ after bacterial challenge. The survival of the mice was monitored for $10 \mathrm{~d}$ and the results analyzed by the log rank test (25) for survival curve determinations. The significance of the number of mice surviving at the end of the experiment was analyzed by either the Fisher exact test (25) when $n<20$ or $\chi^{2}$ analysis (25) when $n>20$.

\section{Results}

A carboxyl terminal peptide from human PF4 has antibacterial activity. Previous work had shown that the carboxyl terminus of human PF4 contained an amphipathic $\alpha$-helical structural motif (18). A peptide corresponding to amino acids 58 through 70, designated C13, was synthesized. Since the amphipathic $\alpha$-helical motif is characteristic of a new group of antibacterial peptides (15), C13 was examined for antibacterial activity. Antibacterial activity was determined in NHS and NHS H-NHS with bacteria that were grown with and without low levels of cefepime (Fig. 1). A concentration of cefepime 


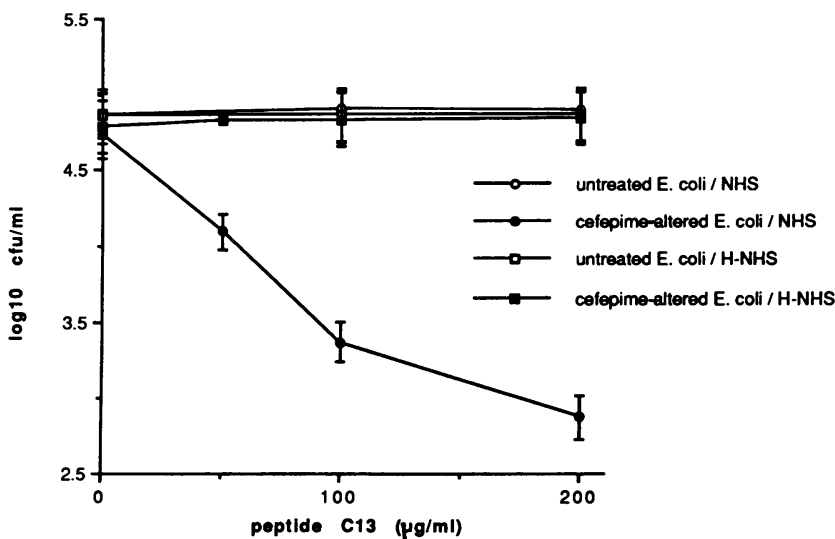

Figure 1. Susceptibility of $E$. coli to peptide $\mathrm{C} 13$ in human serum. $E$. coli ATCC 25922 was grown to mid-log phase without (untreated) and with $0.008 \mu \mathrm{g} / \mathrm{ml}(1 / 8 \mathrm{MIC})$ cefepime (cefepime altered). Bacteria were added to both heat-inactivated $(H-N H S)$ and normal human serum $(N H S)$. The serum $(20 \%)$ contained either no peptide or 50,100 , or $200 \mu \mathrm{g} / \mathrm{ml}$ peptide $\mathrm{C} 13$. Viable counts were determined at the time of bacterial addition to serum (input without cefepime, $4.04 \pm 0.11$; and with cefepime, $4.07 \pm 0.08 \log _{10} \mathrm{CFU} / \mathrm{ml}$ ) and after $3 \mathrm{~h}$ for each sample. The assay was able to accurately detect values between 5.0 and $2.78 \log _{10} \mathrm{CFU} / \mathrm{ml}$. Each assay was performed in triplicate on three separate occasions with the same serum source. Mean \pm 1 SD are shown.

was chosen that had no effect on cell viability in the assay. In addition, an $E$. coli strain was selected that was completely resistant to the bactericidal action of serum. Under these conditions peptide $\mathrm{C} 13$ had a significant antibacterial effect $(P$ $<0.05$, two-sample $t$ test for each peptide concentration examined) when bacteria grown in low levels of cefepime were examined in NHS. In contrast to the data obtained in NHS, no antibacterial activity of peptide $\mathrm{C} 13$ was detected in the absence of cefepime or in H-NHS with or without cefepime.

The role of peptide secondary structure in antibacterial activity was examined. Edmundson wheel projections (26) were used to design peptide analogues of $\mathrm{C} 13$ that would be significantly less $\alpha$-helical or amphipathic. Peptide analogue C13A was designed to disrupt the $\alpha$-helical nature of the peptide by two proline replacements, whereas analogue $\mathrm{C} 13 \mathrm{~B}$ was designed to reduce the amphipathic nature of the peptide by exchanging charged residues and hydrophobic ones in two places. Antibacterial activity was examined in NHS on bacteria grown in low levels of cefepime. In contrast to peptide $\mathrm{C13}$, at a concentration of $200 \mu \mathrm{g} / \mathrm{ml}$ these peptides were not antibacterial ( Table I).

Peptide analogues of $\mathrm{C} 13$ with increased antibacterial activity. Edmundson wheel projections were used to design peptide analogues that differed in the predicted location and type of charge, degree of $\alpha$-helicity, or number of helical turns. All analogues were designed to maintain both the $\alpha$-helical and amphipathic nature of the peptide. A total of 40 different peptide analogues was synthesized. The objective was to determine if the unique antibacterial activity of peptide C13 against cefepime-altered bacteria in NHS could be increased. Peptide analogues of $\mathrm{C} 13$ were examined for potential antibacterial activity in NHS with bacteria grown in low levels of cefepime. The antibacterial potential of the analogues was determined by titrating the peptide analogue from a concentration which did not inhibit bacterial growth, up to $200 \mu \mathrm{g} / \mathrm{ml}$. Two peptide
Table I. Effect of Structural Motif on Antibacterial Activity

\begin{tabular}{llc}
\hline \multicolumn{1}{c}{$\begin{array}{c}\text { Peptide } \\
\text { designation }\end{array}$} & \multicolumn{1}{c}{ Sequence } & Percent survival* \\
\hline C13 & PLYKKIIKKLLES & $7 \pm 2$ \\
C13A & PLYKKPIKKPLES & $535 \pm 74$ \\
C13B & PLKKYIIKKELLS & $478 \pm 31$ \\
No peptide control & & $446 \pm 64$ \\
\hline
\end{tabular}

* The percent survival was determined as described in Methods for strain ATCC 25922 grown with $0.008 \mathrm{mg} / \mathrm{ml}$ cefepime (1/8 MIC) and assayed in $20 \%$ NHS. Peptides were examined at $200 \mu \mathrm{g} / \mathrm{ml}$. Experiments were performed on three separate occasions and the mean $\pm 1 \mathrm{SD}$ are presented.

analogues yielded the most significant increase in antibacterial activity (Fig. 2). An increase of five amino acids predicted to generate another amphipathic $\alpha$-helical loop at the carboxyl terminus and the replacement of proline with alanine at the amino terminus yielded analogue $\mathrm{C} 18 \mathrm{H}$. This analogue demonstrated approximately one log increase in antibacterial activity compared to $\mathrm{C} 13$ (Fig. 2). Another log increase in antibacterial activity was obtained when a glutamic acid residue was replaced with a lysine and two isoleucines were changed to leucines to form peptide analogue C18G (Fig. 2; see Table II for sequence of peptide analogues). Other experiments demonstrated that the two leucine to isoleucine substitutions (from $\mathrm{C} 18 \mathrm{H}$ to $\mathrm{Cl} 18 \mathrm{G}$ ) did not significantly affect antibacterial activity (data not shown).

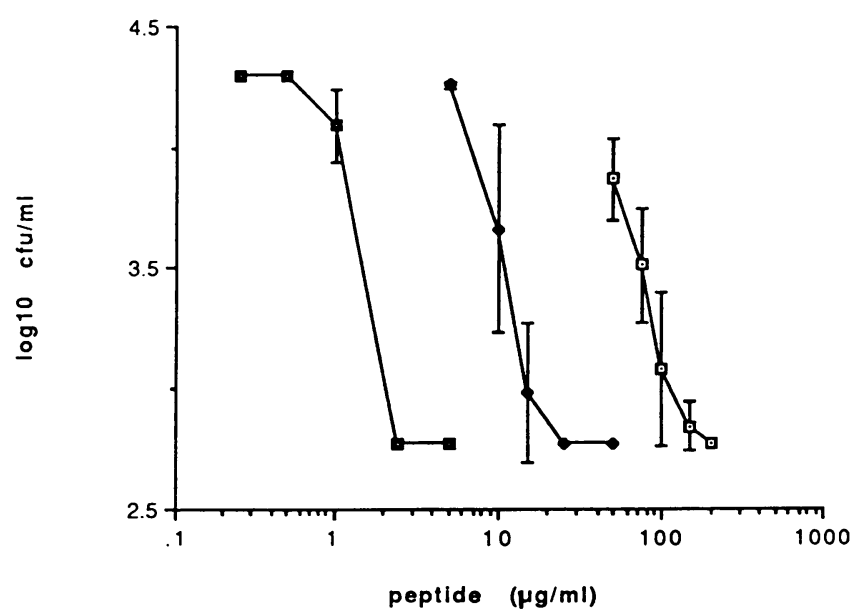

Figure 2. Antibacterial dose response of peptide $\mathrm{C} 13$ and two analogues in normal human serum. E. coli ATCC 25922 was grown to mid-log phase with $0.008 \mu \mathrm{g} / \mathrm{ml}$ ( $1 / 8 \mathrm{MIC})$ cefepime. Bacteria were added to $20 \%$ normal human serum that contained varying amounts of peptide $\mathrm{C} 13$ or analogues $\mathrm{C} 18 \mathrm{H}$ or $\mathrm{C18G}$. The amounts examined were: of C13 (๑) $-200,150,100,75$, and $50 \mu \mathrm{g} / \mathrm{ml}$; of $\mathrm{Cl} 18 \mathrm{H}(\bullet)$ $-50,25,15,10$, and $5 \mu \mathrm{g} / \mathrm{ml}$; and of $\mathrm{C} 18 \mathrm{G}(\square)-5,2.5,1,0.5$, and $0.25 \mu \mathrm{g} / \mathrm{ml}$. Viable counts were determined at the time of bacterial addition to serum (input was $4.06 \pm 0.05 \log _{10} \mathrm{CFU} / \mathrm{ml}$ ) and after 3 $\mathrm{h}$ for each sample. Samples incubated without peptide contained $>4.3 \log _{10} \mathrm{CFU} / \mathrm{ml}$ after $3 \mathrm{~h}$. The assay was able to accurately detect values between 4.3 and $2.78 \log _{10} \mathrm{CFU} / \mathrm{ml}$. Each assay was performed in triplicate on three separate occasions with the same serum source. Mean \pm 1 SD are shown. 
A more thorough analysis of the antibacterial activity of these two analogues compared to peptide $\mathrm{C} 13$ was performed. Titrations of analogues $\mathrm{C} 18 \mathrm{H}$ and $\mathrm{C18G}$ were performed with cells grown with and without low levels of cefepime in H-NHS and NHS. The peptides were also examined for their ability to lyse human red blood cells. These results are summarized in Table II. The antibacterial activity of peptide analogue $\mathrm{C18G}$ was greater than $\mathrm{C} 13$ in all assay conditions. Although $E$. coli ATCC 25922 was completely resistant to NHS in the absence of peptide (see Fig. 1 and the legend to Fig. 2), peptide analogue $\mathrm{C} 18 \mathrm{G}$ was significantly more potent in NHS when compared to H-NHS. In addition, although cefepime augmented the action of peptides $\mathrm{C} 13$ and $\mathrm{C} 18 \mathrm{H}$, no difference in antibacterial activity was observed when $\mathrm{C} 18 \mathrm{G}$ was examined. In contrast to the increase in antibacterial activity, there was no increase in the hemolytic activity of $\mathrm{C18G}$ when compared to $\mathrm{C} 13$. In summary, this analysis revealed that peptide $\mathrm{C} 18 \mathrm{G}$ was $\sim 80$-fold more active than $\mathrm{C} 13$ when examined in NHS on bacteria incubated with or without low levels of cefepime.

Demonstration that complement augments peptide C18G antibacterial activity in human serum. The more potent antibacterial activity of peptide $\mathrm{C} 18 \mathrm{G}$ in NHS compared to $\mathrm{H}$ NHS suggested that complement was required for optimal peptide activity in human serum. Therefore, the antibacterial activity of peptide $\mathrm{C} 18 \mathrm{G}$ was further examined in sera that had been specifically depleted in complement protein C8. In two separate experiments the antibacterial activity of $\mathrm{C} 18 \mathrm{G}$ was determined in C8-deficient and C8-replenished sera with bacteria grown with and without low levels of cefepime (Fig. 3; only the results from experiments without cefepime are presented). In the absence of peptide $\mathrm{C} 18 \mathrm{G}$, or when $\mathrm{C} 8$ was absent from the serum, bacteria grew in the assay. In contrast, when both $\mathrm{C} 8$ and peptide were present there was at least one log decrease from the bacterial input. These data demonstrate that the late components of the complement pathway greatly potentiate the antibacterial activity of $\mathrm{C} 18 \mathrm{G}$ in NHS.

Table II. Antibacterial and Hemolytic Activity of Peptide C13 from Human PF4 and Two Peptide Analogues

\begin{tabular}{lcccccc}
\hline & \multicolumn{4}{c}{ Antibacterial activity* $\left(\mathrm{ID}_{90}\right)$} \\
\cline { 2 - 3 } $\begin{array}{c}\text { Peptide } \\
\text { designation }\end{array}$ & Cefepime & $\begin{array}{c}\text { No } \\
\text { cefepime }\end{array}$ & Cefepime & $\begin{array}{c}\text { No } \\
\text { cefepime }\end{array}$ & $\begin{array}{c}\text { RBC lysis } \\
\left(100 \mu \mathrm{g} / \mathrm{ml}^{*}\right)\end{array}$ \\
\cline { 2 - 3 } C13 & $75-100$ & $>200$ & $>200$ & $>200$ & $<1$ \\
C18H & $5-15$ & $15-25$ & $100-200$ & $>200$ & 1.5 \\
C18G & $1-2.5$ & $1-2.5$ & $50-100$ & $50-100$ & $<1$
\end{tabular}

\footnotetext{
* Antibacterial activity against $E$. coli ATCC 25922 was determined in three separate experiments for each experimental condition. The range of peptide concentration $(\mu \mathrm{g} / \mathrm{ml})$ which reduced the bacterial input by one $\log$ is reported. The assay contained $20 \%$ NHS or HNHS, cefepime when present was added to $0.008 \mu \mathrm{g} / \mathrm{ml}(1 / 8 \mathrm{MIC})$. ${ }^{\ddagger}$ Red blood cell hemolysis assays were conducted on three separate occasions and the percent lysis at $100 \mu \mathrm{g} / \mathrm{ml}$ of peptide is reported. The peptide sequence for $\mathrm{C} 13$ is found in Table $\mathrm{I}$, the peptide sequence for $\mathrm{C} 18 \mathrm{H}$ and $\mathrm{C} 18 \mathrm{G}$ is:
}

\section{C18H; ALYKKIIKKLLESAKKLG}

C18G: ALYKKLLKKLLKSAKKLG

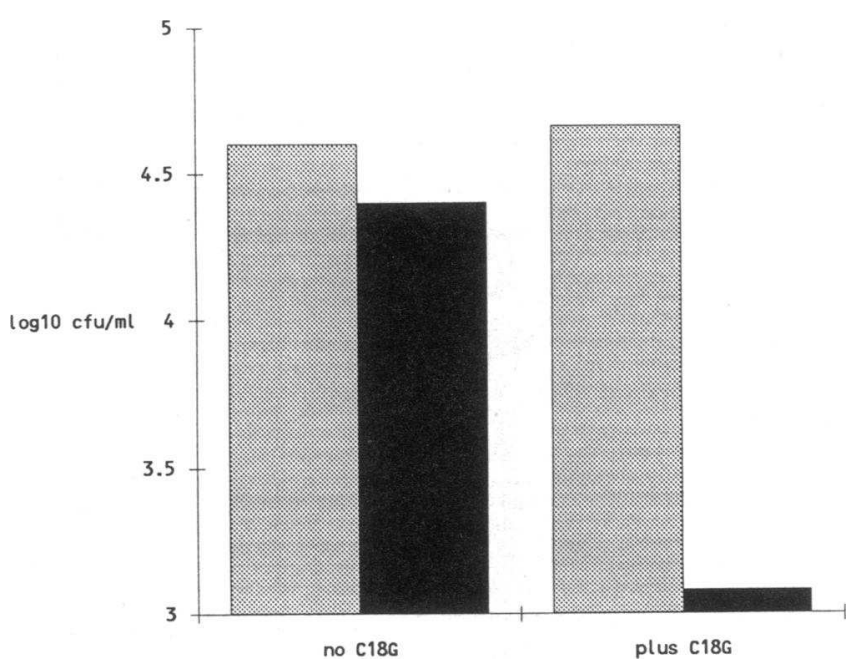

Figure 3. Antibacterial activity of peptide C18G in C8-deficient and C8-repleated human sera. E. coli $\mathrm{AP}$ was added to either $40 \%$ human serum specifically depleted in C8 (C8d) (gray bars) or C8d serum to which $\mathrm{C} 8$ was added back to physiological concentrations $(50 \mu \mathrm{g} / \mathrm{ml})$ (black bars). Viable counts were determined at the time of bacterial addition to serum (bacterial input was $3.95 \log _{10} \mathrm{CFU} / \mathrm{ml}$ ) and after $3 \mathrm{~h}$ incubation at $37^{\circ} \mathrm{C}$. The assay was able to accurately detect values between 5.0 and $3.08 \log _{10} \mathrm{CFU} / \mathrm{ml}$. Two separate experiments were performed which yielded similar results and the average is presented.

Antibacterial activity of peptide C18G with several different bacterial strains. The antibacterial activity of peptide C18G was examined with four different bacterial strains (Fig. 4). Antibacterial activity was determined in NHS and H-NHS on bacteria incubated with and without low levels of cefepime. Initial experiments determined the serum susceptibility of the different bacterial strains. A concentration of serum was then chosen for each strain that did not reduce the bacterial input during the course of the assay. At the peptide concentrations examined, significant antibacterial activity was observed with peptide $\mathrm{C} 18 \mathrm{G}$ in NHS but not in H-NHS for each strain examined. Similar to what was observed with $E$. coli A645 (Table II), the antibacterial activity of $\mathrm{C} 18 \mathrm{G}$ was not enhanced by low levels of cefepime when $K$. pneumoniae was examined. In contrast, with the three other strains examined in Fig. 4, low levels of cefepime rendered the bacteria more susceptible to the antibacterial action of the peptide. These results demonstrated that the antibacterial activity of peptide $\mathrm{C} 18 \mathrm{G}$ was potentiated by NHS for a variety of different bacterial strains.

Animal studies. Initial experiments examined the ability of peptide $\mathrm{C} 13$ alone and in combination with low levels of cefepime to protect neutropenic mice from a lethal dose of $E$. coli. Mice were challenged with $2 \times 10^{4} E$. coli $\mathrm{H} 16$ by intraperitoneal injection, divided into four separate treatment groups, and their survival was monitored for $10 \mathrm{~d}$ (Fig. 5). Mice that were administered the combination of low levels of cefepime and peptide $\mathrm{C} 13$ had a significantly higher survival rate in the first 3 d when compared to treatment with either low levels of cefepime, peptide $C 13$, or PBS $(P<0.005, \log$ rank test $)$. However, at the end of the experiment ( $10 \mathrm{~d}$ after infection) there was no significant difference in the total number of survivors from each treatment group $(P>0.05$, Fisher exact test $)$. The combination of peptide $\mathrm{C} 13$ and a low level of cefepime could delay 

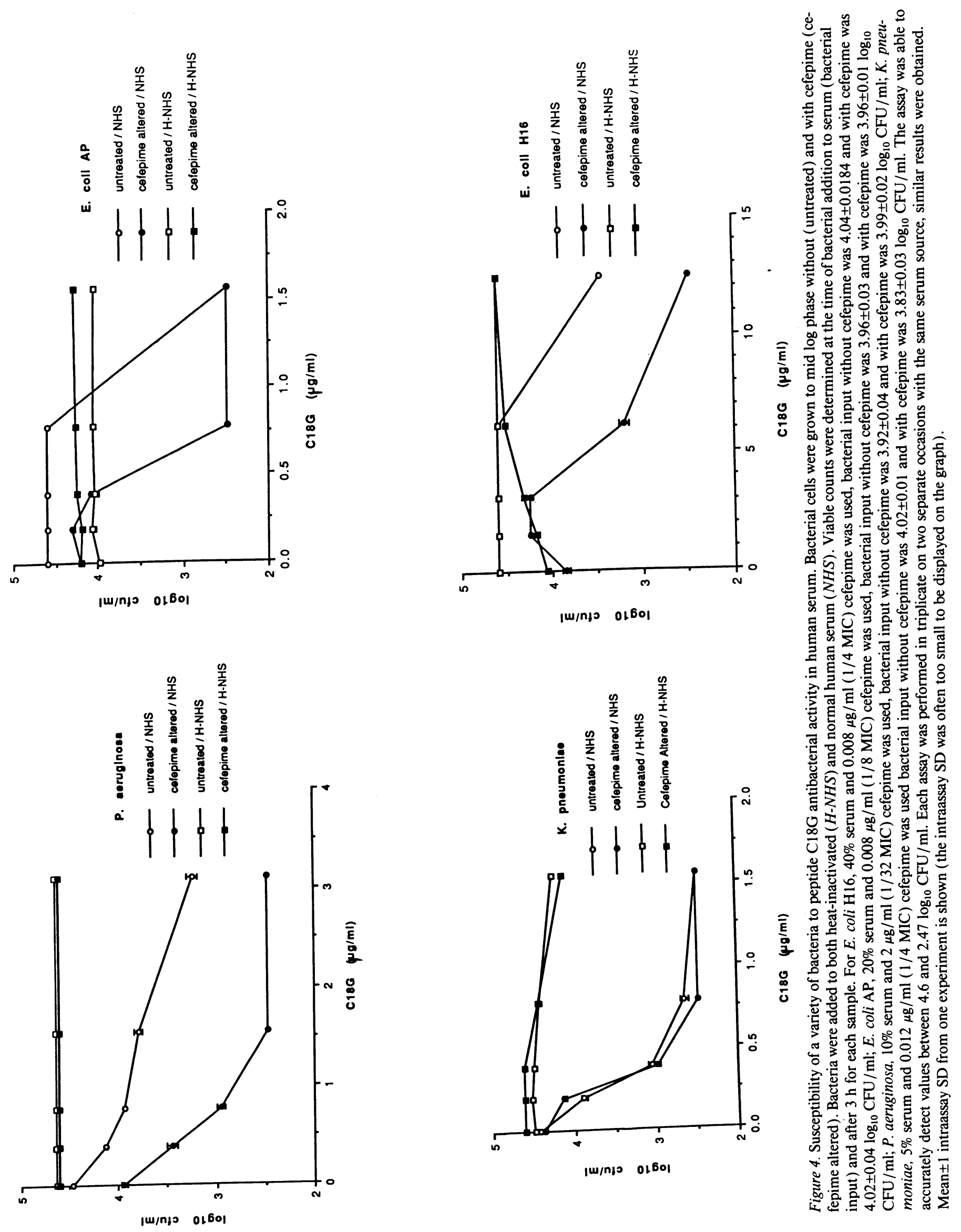


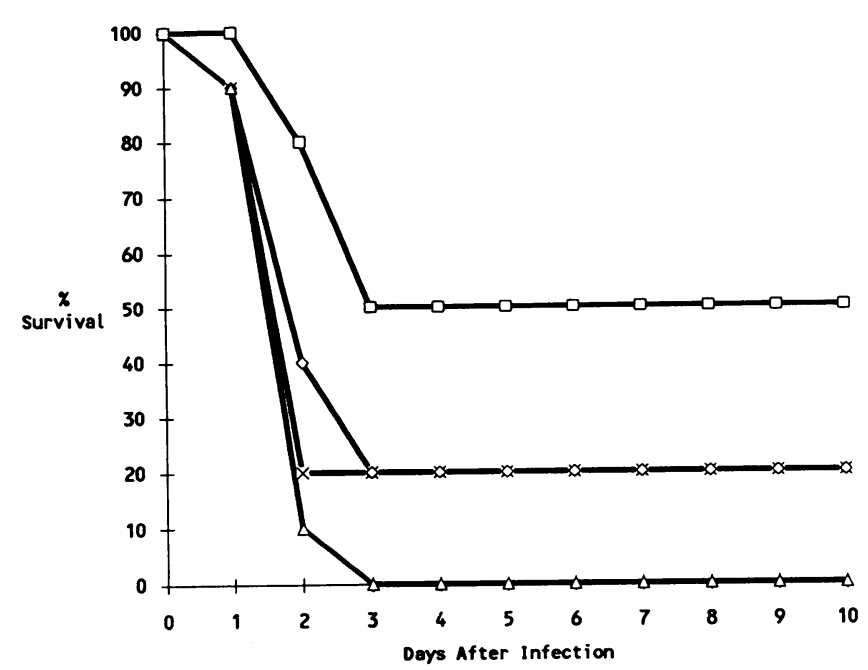

Figure 5. Peptide $\mathrm{C} 13$ and cefepime combination treatment for a systemic $E$. coli infection. Mice were challenged with $E$. coli $\mathrm{H} 16$ as described in the text. Ten mice were present in each of four separate treatment groups which consisted of the following: (X) PBS; $(\diamond)$ cefepime, $0.2 \mathrm{mg} / \mathrm{kg}$; $(\Delta) \mathrm{C13}, 3 \mathrm{mg} / \mathrm{mouse}$; () $\mathrm{C} 13$ + cefepime, a combination of $0.2 \mathrm{mg} / \mathrm{kg}$ cefepime and $3 \mathrm{mg}$ per mouse $\mathrm{C} 13$. The number of mice surviving each day after infection was recorded for $10 \mathrm{~d}$ at which time no visible symptoms of the infection were evident (no change the survival of the mice was observed after day 3 ).

but not significantly prevent death due to the bacterial infection.

Next the ability of peptide analogue $\mathrm{C} 18 \mathrm{G}$ both alone and in combination with low levels of cefepime to protect mice from a lethal $E$. coli infection was examined (Fig. 6). Four separate experiments were performed with strain $\mathrm{H} 16$ each containing a group of mice that were treated with PBS as a control as well as a group that was given a low level of cefepime. There was no significant difference $\left(P>0.1, \chi^{2}\right.$ test $)$ in the survival of mice given cefepime $(0.2 \mathrm{mg} / \mathrm{kg})$ compared to the treatment group given PBS. In addition, the administration of up to $2 \mathrm{mg}$ per mouse of $\mathrm{C} 18 \mathrm{G}$ alone also did not significantly improve the survival of the mice $(P>0.05$, Fisher exact test $)$. In contrast, there was a significant $\left(P<0.001, \chi^{2}\right.$ test $)$ increase in the survival of mice given a combination of $0.5 \mathrm{mg}$ of $\mathrm{Cl} 18 \mathrm{G}$ per mouse and a low level of cefepime. The combination of 2 $\mathrm{mg}$ of $\mathrm{C} 18 \mathrm{G}$ per mouse and a low level of cefepime also resulted in a significant $(P<0.05$, Fisher exact test $)$ increase in the survival of the mice. Similar results were obtained when experiments with $E$. coli AP were performed. The majority of mice that were given either PBS ( 17 dead of 20 total); 0.2 $\mathrm{mg} / \mathrm{kg}$ cefepime ( 17 dead of 20 total ); or $0.5 \mathrm{mg} / \mathrm{mouse} \mathrm{C18G}$ ( 15 dead of 15 total) died during the course of the experiment. However, when $\mathrm{C18G}$ and cefepime were coadministered (in the amounts given above), there was a significant increase ( $P$ $<0.05$, Fisher exact test) in the survival of the mice ( 8 alive of 15 total).

Additional animal protection experiments were performed with $E$. coli $\mathrm{H} 16$ to examine the therapeutic potential of an all $\mathrm{D}$ amino acid containing analogue of $\mathrm{C} 18 \mathrm{G}$, designated $\mathrm{C} 18 \mathrm{X}$ (Table III), and separately to examine the combination of C18G and aztreonam, another $\beta$-lactam antibiotic (Table IV). Mice were divided into four experimental treatment groups which consisted of PBS, low level of antibiotic, peptide, and combination of peptide and antibiotic. Combination treatment with $\mathrm{C} 18 \mathrm{X}$ (all D analogue) and cefepime resulted in highly significant protection $(P<0.001$, Fisher exact test $)$ when compared to the other treatment groups. The combination treatment with aztreonam and $\mathrm{C} 18 \mathrm{G}$ also resulted in highly significant protection $(P<0.001$, Fisher exact test) when compared to the other treatment groups.

\section{Discussion}

A peptide corresponding to the carboxyl terminus of human PF4 (peptide C13) was found to be antibacterial. This peptide

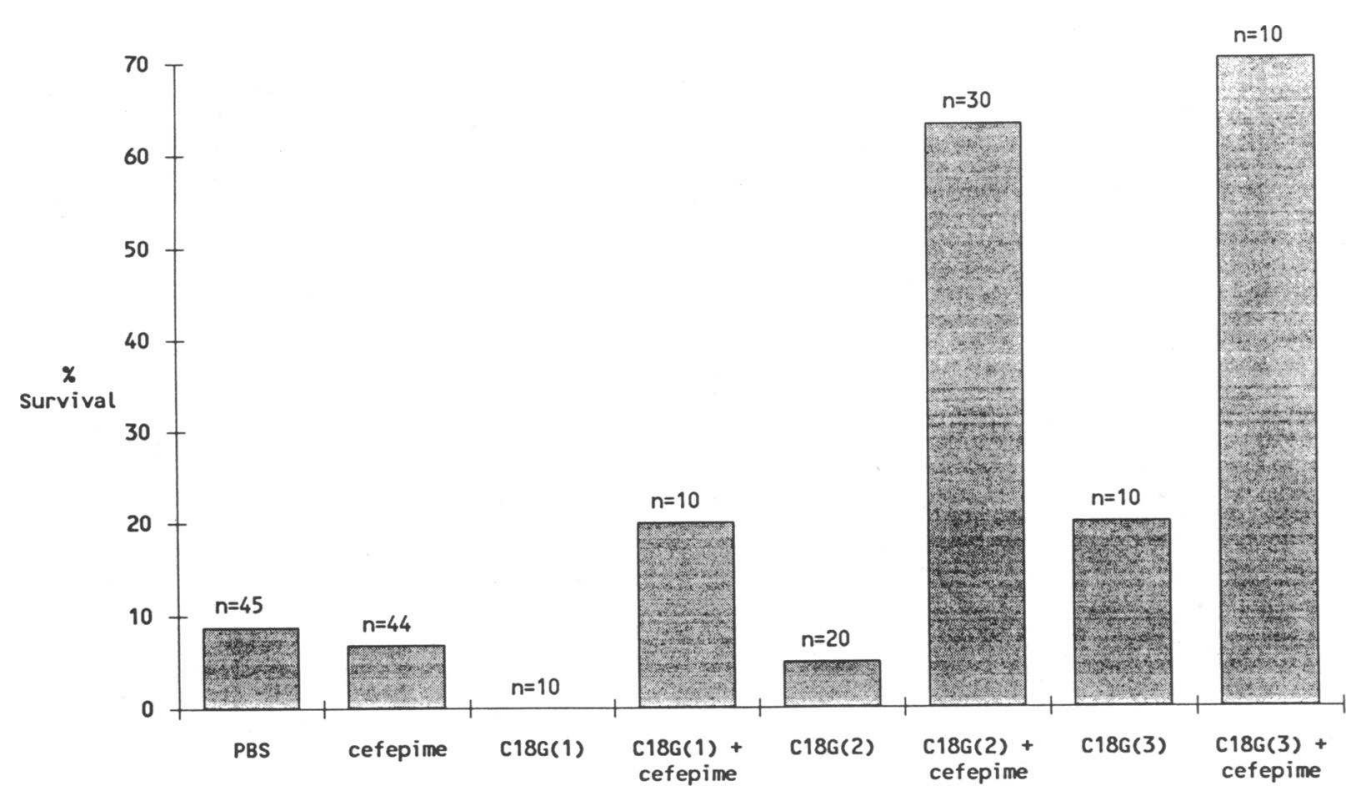

Figure 6. Peptide C18G and cefepime combination treatment for a systemic $E$. coli infection. Mice were challenged with $E$. coli $\mathrm{H} 16$ as described in the text. The number of mice surviving 10 $\mathrm{d}$ after infection (at which time no visible symptoms of the infection were evident) were recorded. Mice were divided into separate treatment groups which consisted of the following: PBS; cefepime $(0.2 \mathrm{mg} / \mathrm{kg})$; and three concentrations of $\mathrm{C} 18 \mathrm{G}$ (C18G[1], $0.2 \mathrm{mg} / \mathrm{mouse}$ $\mathrm{C} 18 \mathrm{G}$ [2], $0.5 \mathrm{mg} / \mathrm{mouse}$; C18G[3] 2 mg per mouse). These concentrations of peptide were examined alone and in combination with cefepime as indicated on the horizontal axis. The cumulative results from four separate experiments are presented. 
Table III. Therapeutic Efficacy of an All D-Analogue (C18X) of C18G in Combination with Low Levels of Cefepime in a Neutropenic Mouse Model of Infection

\begin{tabular}{lcccc}
\hline & \multicolumn{3}{c}{ Treatment group } \\
\cline { 2 - 5 } & PBS & Cefepime & C18X & Cefepime + C18X \\
\hline & & $(0.2 \mathrm{mg} / \mathrm{kg})$ & $(0.5 \mathrm{mg} \mathrm{per} \mathrm{mouse)}$ & $(0.2 \mathrm{mg} / \mathrm{kg}+0.5 \mathrm{mg} \mathrm{per} \mathrm{mouse)}$ \\
Number of mice alive/total & $2 / 25$ & $3 / 25$ & $2 / 18$ & $15 / 20$ \\
Percent servival & 8 & 12 & 11 & $75^{*}$ \\
\hline
\end{tabular}

${ }^{*} P<0.001$, Fisher exact test.

is significantly different from naturally occurring antibacterial peptides $(15,27)$ and represents a novel amino acid sequence forming an amphipathic $\alpha$-helical motif that contains antibacterial activity. The role of this motif in naturally occurring antibacterial peptides is currently under investigation by several different laboratories $(15,27,28)$. Modifications of amino acid sequence (29) as well as chimeric (30) peptides are being studied in order to determine the potential clinical utility of this new class of antibacterials. In addition, antibacterial activity has been reported with peptides corresponding to amphipathic $\alpha$-helical sequences in other naturally occurring proteins (3133). However, antibacterial activity was either too limited (33) or potentially toxic (due to lysis of human red blood cells) ( 31 , 32 ) to be clinically useful. In contrast, the results of this study demonstrated that $\mathrm{C} 13$ was antibacterial at concentrations of peptide that did not lyse human red blood cells. Peptide C13 therefore provided a unique amino acid sequence with clinically relevant antibacterial activity.

More potent analogues of $\mathrm{C} 13$ were designed and evaluated. Peptide $\mathrm{C} 13$ was similar to magainin 2 (14) in its requirement for NHS and low levels of cefepime for optimal antibacterial activity. Therefore, the evaluation of peptides derived from C13 for antibacterial activity was conducted in NHS with bacteria exposed to low levels of cefepime. This approach insured that those peptides that required the host immune system for optimal antibacterial activity would be identified. An initial evaluation of potentially new antibacterial agents in assay systems that employ human serum as contrasted to broth was proposed over 15 years ago (34). However, perhaps because of the advent of more potent bactericidal antibiotics, little information has appeared in the literature concerning this approach (5). An increased awareness of the role of the host immune system in the eradication of bacterial infections (5), a need for improved therapy for neutropenic patients (1), as well as encouraging data obtained from in vitro and in vivo studies with magainin 2 (14), prompted us to deviate from standard antibacterial drug discovery assays. In a study of 40 peptide analogues, two were identified that possessed significant increases in antibacterial activity. Extending the length of peptide $\mathrm{C} 13$ and the substitution of a negative with a positive charge resulted in peptide $\mathrm{C} 18 \mathrm{G}$ which was 80 -fold more active than $\mathrm{C} 13$.

Studies in sera depleted of complement protein C8 confirmed that peptide analogue $\mathrm{C} 18 \mathrm{G}$ required complement for optimal peptide activity. This is similar to magainin 2 (14) and other cationic peptides $(35,36)$ that have been shown to render bacteria more susceptible to serum bactericidal activity. Studies with NHS and H-NHS with several bacterial strains are consistent with a strong complement requirement for optimal antibacterial activity of the peptide. The addition of low levels of cefepime augmented the peptide antibacterial action for some strains but not others. Independently, low levels of cefepime have been shown to increase bacterial susceptibility to serum by allowing more effective C5b-9 deposition on the altered bacterial cell surface (12). Initial studies show that addition of peptide $\mathrm{C} 18 \mathrm{G}$ results in significantly more $\mathrm{C} 5 \mathrm{~b}-9$ deposition (data not shown); however, the molecular interaction between the cefepime altered bacterial cell, antimicrobial peptide, and complement remains unclear. Peptide $\mathrm{C} 18 \mathrm{X}$, an all $D$ analogue, showed similar antibacterial activity in vitro (data not shown) as well as in mouse protection experiments. This indicates that those aspects of peptide action that require serum complement for optimal activity do not involve specific enzymes or chiral receptors. Wade et al. (15) have shown that $D$ enantiomers of three naturally occurring peptide antibiotics retain antibacterial activity. A possible hypothesis is that pep-

Table IV. Therapeutic Efficacy of the Combination of C18G and Low Levels of Aztreonam (Another B-Lactam Antibiotic) in a Neutropenic Mouse Model of Infection

\begin{tabular}{lcccc}
\hline & \multicolumn{3}{c}{ Treatment Group } \\
\cline { 2 - 5 } & PBS & Aztreonam & C18G & Aztreonam + C18G \\
\hline & control & $(1 \mathrm{mg} / \mathrm{kg})$ & $(0.5 \mathrm{mg}$ per mouse $)$ & $(1 \mathrm{mg} / \mathrm{kg}+0.5 \mathrm{mg} \mathrm{per} \mathrm{mouse})$ \\
Number of mice alive/total & $0 / 9$ & $1 / 20$ & $0 / 20$ & $11 / 20$ \\
Percent survival & 0 & 5 & 0 & $55^{*}$ \\
\hline
\end{tabular}

$* P<0.001$, Fisher exact test. 
tide $\mathrm{C} 18 \mathrm{G}$, in combination with serum complement (37) disrupts the bacterial outer membrane. This disruption results in access of both the peptide and / or terminal complement components to critical sites in the bacterial cell envelope. $\beta$-lactam type antibiotics which are known to affect the outer membrane (38) may augment this process in some strains.

We explored the possibility that other closely related sequences would be antibacterial with serum complement. Peptides derived from the amphipathic $\alpha$-helical motif found at the carboxyl terminus of an interferon-inducible protein designated IP 10 (39) were synthesized. This cytokine is a member of the same IL-8 cytokine family, as is PF4 (40). The carboxyl terminus of IP 10 has been postulated to be cleaved (39). This suggested to us the potential for an endogenous antibacterial peptide which may serve as an adjunct to serum mediated killing. Serum factors that augment complement-mediated killing have been postulated by others $(41,42)$. However, antibacterial activity was not found when three different peptide sequences from the carboxyl terminus of IP 10 were examined in our assay (data not shown). In a related finding, other peptide analogues of $\mathrm{C} 13$ were also found to be inactive, although based on Edmundson wheel projections they should have maintained the correct secondary structure (data not shown). Further studies will be necessary to determine the relationship between secondary structure, amino acid sequence, and antibacterial activity for this unique group of antibacterial peptides.

In vivo protection studies with $E$. coli demonstrated that peptide $\mathrm{C} 18 \mathrm{G}$ when combined with low levels of cefepime was able to significantly protect mice from a lethal infection. Significant protection was also observed when peptide $\mathrm{C} 18 \mathrm{G}$ was coadministered with aztreonam, another $\beta$-lactam antibiotic. Although other $\beta$-lactam antibiotics were not employed in this study, earlier work $(12,14)$ would indicate that this class of antibiotics but not aminoglycosides nor quinolones augment bacterial killing by serum and peptide. The animal experiments are similar to those previously conducted with magainin 2 (14) where low levels of cefepime were employed to mimic clinical failure of the antibiotic. Administration of low levels of antibiotic were necessary to determine if the peptide would augment protection. Clinically, antibiotics may not reach sufficient concentration at their bacterial targets due to both bacterial resistance and/or impaired drug access, or the existence of local environmental conditions that are antagonistic to antibiotic action. Insufficient antibiotic concentrations may be more effective in the immunosufficient host where injured bacteria are removed by the host defense system. These studies further support the notion (14) that augmentation of antibiotic therapy with peptides or other agents that take advantage of antibiotic-altered bacteria may be beneficial for the neutropenic patient.

\section{Acknowledgments}

We thank Perry Fell, John Somerville, and Leah Lipsich for critically reading the manuscript and Ana Wieman for preparation of the manuscript. We also thank Perry Fell for his constant support and enthusiasm.

\section{References}

1. Klastersky, J., S. H. Zinner, T. Calandra, H. Gaya, M. P. Glauser, F. Meunier, M. Rossi, S. C. Schimpff, M. Tattersall, and C. Viscoli. 1988. Antimi- crobial therapy for febrile granulocytopenic cancer patients: lessons from four EORTC trials. Eur. J. Cancer Clin. Oncol. 24:S35-45.

2. Sechler, J. M. G., H. L. Malech, C. J. White, and J. I. Gallin. 1988. Recombinant human interferon-gamma reconstitutes defective phagocyte function in patients with chronic granulomatous disease of childhood. Proc. Natl. Acad. Sci. USA. 85:4874-4878.

3. Tanaka, T., S. Okamura, K. Okada, A. Suga, N. Shimono, N. Ohhara, Y Hirota, Y. Sawae, and Y. Niho. 1989. Protective effect of recombinant murine granulocyte-macrophage colony-stimulating factor against Pseudomonas aeruginosa infection in leukocytopenic mice. Infect. Immun. 57:1792-1799.

4. Gabrilove, J. L., A. Jakubowski, H. Scher, C. Sternberg, G. Wong, J. Grous, A. Yagoda, K. Fain, M. A. S. Moore, B. Clarkson, et al. 1988. Effect of granulocyte colony-stimulating factor on neutropenia and associated morbidity due to chemotherapy for transitional-cell carcinoma of the urothelium. N. Engl. J. Med. 318:1414-1422.

5. Pruul, H., and P. J. McDonald. 1988. Damage to bacteria by antibiotics in vitro and its relevance to antimicrobial chemotherapy: a historical perspective. $J$. Antimicrob. Chemother. 21:695-700.

6. Neu, H. C. 1991. New strategies for the 1990's: antibacterial therapy. Int. J. Antimicrob. Agents. 1:47-50.

7. Hammer, M. C., A. L. Baltch, R. P. Smith, J. V. Conroy, M. Bishop, P. Michelsen, and L. Hill. 1988. Human granulocyte activity against moxalactaminduced filamentous forms of Pseudomonas aeruginosa. Antimicrob. Agents Chemother. 32:1565-1570.

8. Pruul, H., G. Lewis, and P. J. McDonald. 1988. Enhanced susceptibility of gram-negative bacteria to phagocytic killing by human polymorphonuclear leucocytes after brief exposure to aztreonam. J. Antimicrob. Chemother. 22:675686.

9. Gerber, A. U., H.-P. Brugger, C. Feller, T. Stritzko, and B. Stalder. 1986. Antibiotic therapy of infections due to Pseudomonas aeruginosa in normal and granulocytopenic mice: comparison of murine and human pharmacokinetics. $J$. Infect. Dis. 153:90-97.

10. Opferkuch, W., K. -H. Buscher, H. Karch, H. Leying, M. Pawelzik, U. Schumann, and C. Wiemer. 1985. The effect of sublethal concentrations of antibiotics on the host parasite relationship. Zbl. Bakteriol. Suppl. 31:165-177.

11. Taylor, P. W., H. Gaunt, and F. M. Unger. 1981. Effect of subinhibitory concentrations of mecillinam on the serum susceptibility of Escherichia coli strains. Antimicrob. Agents Chemother. 19:786-788.

12. Darveau, R. P., and M. D. Cunningham. 1990. Influence of subinhibatory concentrations of cephalosporins on the serum sensitivity of Pseudomonas aeruginosa. J. Infect. Dis. 162:914-921.

13. Zasloff, M. 1987. Magainins, a class of antimicrobial peptides from Xenopus skin: Isolation, characterization of two active forms, and partial cDNA sequence of a precursor. Proc. Natl. Acad. Sci. USA. 84:5449-5453.

14. Darveau, R. P., M. D. Cunningham, C. L. Seachord, L. Cassiano-Clough, W. L. Cosand, J. Blake, and C. S. Watkins. 1991. $\beta$-lactam antibiotics potentiate magainin 2 antimicrobial activity in vitro and in vivo. Antimicrob. Agents Chemother. 35:1153-1159.

15. Wade, D., A. Boman, B. Wahlin, C. M. Drain, D. Andreu, H. G. Boman, and R. B. Merrifield. 1990. All-D amino acid-containing channel-forming antibiotic peptides. Proc. Natl. Acad. Sci. USA. 87:4761-4765.

16. Lee, S., M. Yoshida, H. Mihara, H. Aoyagi, T. Kato, and N. Yamasaki. 1989. The spectroscopic analysis for binding of amphipathic and antimicrobial model peptides containing pyrenylalanine and tryptophan to lipid bilayer. Biochim. Biophys. Acta. 984:174-182.

17. Kaiser, E. T., and F. J. Kezdy. 1984. Amphiphilic secondary structure: design of peptide hormones. Science (Wash. DC). 223:249-255.

18. Clore, G. M., E. Appella, M. Yamada, K. Matsushima, and A. M. Gronenborn. 1990. Three-dimensional structure of interleukin 8 in solution. Biochemistry. 29:1689-1696.

19. Jones, R. N., A. L. Barry, T. L. Gavan, and J. A. Washington II. 1985. Susceptibility tests: microdilution and macrodilution broth procedures. In Manual of Clinical Microbiology. Edwin H. Lennette, editor. American Society for Microbiology, Washington, DC. 972-977.

20. Merrifield, R. B. 1963. Solid phase synthesis. I. The synthesis of a tetrapeptide. J. Am. Chem. Soc. 85:2149-2154.

21. Sakakibara, S., Y. Shimonishi, Y. Kishida, M. Okada, and H. Sugihara. 1967. Use of anhydrous hydrogen fluoride in peptide synthesis. I. Behavior of various protective groups in anhydrous hydrogen fluoride. Bull. Chem. Soc. Jpn. 40:2164-2167.

22. Koch, A. L. 1981. Growth measurement: colony counts. In A Manual of Methods for General Bacteriology. R. N. Costilow, editor. American Society for Microbiology, Washington, DC. 185-188.

23. Geoffrey, C., J. L. Gaillard, J. E. Alouf, and P. Berche. 1987. Purification, characterization and toxicity of the sulfhydryl-activated hemolysin listeriolysin $\mathrm{O}$ from L. monocytogenes. Infect. Immun. 55:1641-1646.

24. Finney, D. J. 1971. In Probit Analysis. Cambridge University Press, London. 20-49. 
25. Matthews, D. E., and V. T. Farewell. 1985. Untitled chapter. In Using and Understanding Medical Statistics. S. Karger, Basel. 20-46.

26. Schiffer, M., and A. B. Edmundson. 1967. Use of helical wheels to represent the structures of proteins and to identify segments with helical potential. Biophys. J. 7:121-135.

27. Boman, H. G. 1991. Antibacterial peptides: key components needed in immunity. Cell. 65:205-207.

28. Nakajima, Y., X-m. Qu, and S. Natori. 1987. Interaction between liposomes and sarcotoxin IA, a potent antibacterial protein of Sarcophaga peregrina (flesh fly). J. Biol. Chem. 262:1665-1669.

29. Cuervo, J. H., B. Rodriguez, and R. A. Houghten. 1988. The magainins: sequence factors relevant to increased antimicrobial activity and decreased hemolytic activity. Pept. Res. 1:81-86.

30. Boman, H. G., D. Wade, I. A. Boman, B. Wahlin, and R. B. Merrifield. 1989. Antibacterial and antimalarial properties of peptides that are cecropin-melittin hybrids. FEBS (Fed. Eur. Biochem. Soc.) Lett. 259:103-106.

31. Sitaram, N., and R. Nagaraj. 1990. A synthetic 13-residue peptide corresponding to the hydrophobic region of bovine seminalplasmin has antibacterial activity and also causes lysis of red blood cells. J. Biol. Chem. 265:10438-10442.

32. Miller, M. A., R. F. Garry, J. M. Jaynes, and R. C. Montelaro. 1991. A structural correlation between lentivirus transmembrane proteins and natural cytolytic peptides. AIDS Res. Hum. Retroviruses. 7:511-519.

33. Lee, S., H. Mihara, H. Aoyagi, T. Kato, N. Izumiya, and N. Yamasaki. 1986. Relationship between antimicrobial activity and amphiphilic property of basic model peptides. Biochim. Biophys. Acta. 862:211-219.
34. Sud, I. J., and D. S. Feingold. 1975. Detection of agents that alter the bacterial cell surface. Antimicrob. Agents Chemother. 8:34-37.

35. Lehrer, R. I., A. Barton, K. A. Daher, S. S. L. Harwig, T. Ganz, and M. E. Selsted. 1989. Interaction of human definsins with Escherichia coli, mechanism of bactericidal activity. J. Clin. Invest. 84:553-561.

36. Vaara, M., and T. Vaara. 1983. Polycations as outer membrane-disorganizing agents. Antimicrob. Agents Chemother. 24:114-122.

37. Tesh, V. L., R. L. Duncan, Jr., and D. C. Morrison. 1986. The interaction of Escherichia coli with normal human serum: the kinetics of serum-mediated lipopolysaccharide release and its dissociation from bacterial killing. J. Immunol. 137:1329-1335.

38. Curtis, N. A. C., R. L. Eisenstadt, K. A. Turner, and A. J. White. 1985. Inhibition of penicillin-binding protein 3 of Escherichia coli K-12. Effects upon growth, viability and outer membrane barrier function. J. Antimicrob. Chemother. 16:287-296.

39. Luster, A. D., and J. V. Ravetch. 1987. Biochemical characterization of a gamma interferon-inducible cytokine (IP-10). J. Exp. Med. 166:1084-1097.

40. Stoeckle, M. Y., and K. A. Barker. 1990. Two burgeoning families of platelet factor 4-related proteins: mediators of the inflammatory response. New Biol. 2:313-323.

41. Clas, F., and M. Loos. 1982. Requirement for an additional serum factor essential for the antibody-independent activation of the classical complement sequence by gram-negative bacteria. Infect. Immun. 37:935-939.

42. Kawakami, M., I. Ihara, A. Suzuki, and Y. Harada. 1982. Properties of a new complement-dependent bactericidal factor specific for Ra chemotype Salmonella in sera of conventional and germ-free mice. J. Immunol. 129:2198-2201. 